\title{
Deriving Compost from Municipal Organic Wastes in Saudi Arabia
}

\author{
Soulman Mutairi', Adel Ghoneim ${ }^{1 *}$, Abdullah Modaihsh', Khaled Alotaibi', \\ Fahad al-Barakah', Mehmood Ali Noor ${ }^{2}$
}

\author{
${ }^{1}$ Department of Soil Sciences, College of Food and Agricultural Sciences, King Saud University, \\ P.O. Box 2460, Riyadh 11451, Saudi Arabia. \\ ${ }^{2}$ Institute of Crop Sciences, Chinese Academy of Agricultural Sciences, Key Laboratory of Crop Physiology \\ and Ecology, Ministry of Agriculture, Beijing 100081, China.
}

Received: 25 December 2017

Accepted: 20 March 2018

\begin{abstract}
The dramatic growth in urbanization and population in Riyadh, Saudi Arabia have brought some environmental challenges that need to be efficiently dealt with. One of these challenges is finding the proper management for hugely produced municipal solid wastes (MSW). Recycling of MSW via composting is a possible option of its management and has recently received more attention, although compost ability and chemical characteristics of resulting compost are not widely studied. Therefore, the aim of this study was to evaluate the characterization of the municipal organic wastes fraction and composting process. In this study, the organic fraction of MSW was composted alone or with a chemical and/or organic additives using a windrows composting system for a period of 12 weeks. Changes in temperature, $\mathrm{EC}, \mathrm{pH}, \mathrm{C} / \mathrm{N}$ ratio, total contents of $\mathrm{Zn}, \mathrm{Fe}, \mathrm{Mn}, \mathrm{Cu}, \mathrm{Cr}, \mathrm{Cd}$, and $\mathrm{Pb}$ were monitored over a regular interval throughout the composting process. All the measured parameters showed great differences among types of compost. The results indicated that medium temperature range was $33-64^{\circ} \mathrm{C}$, EC was 2.85-4.50 dS m $\mathrm{m}^{-1}$, and $\mathrm{pH}$ was 7.50-8.50. Moreover, $\mathrm{C} / \mathrm{N}$ ratio was found within the acceptable average range (8.0-15). The produced composts contained a high level of total $\mathrm{N}(1.80 \%)$, total $\mathrm{P}$ $(0.50 \%)$, and total $\mathrm{K}(0.25 \%)$. The total contents of $\mathrm{Zn}, \mathrm{Fe}, \mathrm{Mn}, \mathrm{Cu}, \mathrm{Cd}, \mathrm{Cr}$, and $\mathrm{Pb}$ were within the permissible limits for compost.
\end{abstract}

Keywords: municipal solid wastes, compost quality, elemental analysis, heavy metals, Riyadh

\section{Introduction}

Municipal solid wastes (MSW) are the most complex solid wastes stream [1]. Riyadh, the capital of

*e-mail: aghoneim@ksu.edu.sa the Kingdom of Saudi Arabia (KSA), is the country's largest city with an area of $1913 \mathrm{~km}^{2}$ and population of 33 million [2]. The city's population has increased rapidly, causing a higher generation rate of MSW that contains both domestic and commercial waste. The large amount of waste creates lots of problems in daily life and for the environment. It requires the application of some effective strategies for 
proper disposal of MSW/organic wastes. With rapid urbanization, Riyadh is facing a massive MSW management challenge. The dramatic urban growth of Riyadh has resulted in a huge amount of MSW being generated on a daily basis. Total MSW generation has increased to more than 12 million tons per year and the per capita MSW in KSA is $1.50-1.80 \mathrm{~kg}^{\text {person }}{ }^{-1}$ day $^{-1}$ [3]. The common method of MSW disposal in the city is landfilling $[4,5]$, which can have negative environmental impacts. In addition, the continual rise in MSW generation will require more new landfills to be constructed, and this will add extra cost that could have been avoided if other options of MSW management had been considered [6-8]. Sustainable waste-management practices in KSA are lacking, and documented information on the quality control processes of waste management in KSA is limited [9].

To sustain and recycle large amounts of MSW, composting is an environmentally friendly option and a good way to transform the municipal organic wastes material into organic fertilizer that can be used in urban and rural agriculture $[10,11]$. Composting is one of the best technologies to treat MSW in a more sustainable way. For many decades composting has been used for recycling solid waste organic matter as it improves soil fertility and structure while maintaining the moisture content of the soil [11]. Production of MSW continues to rise, which causes loss of resources and increased environmental risks [12]. Open dumping and landfilling will cause environmental degradation and harmful diseases. Composting MSW is an alternative to the disposal of significant amounts of the waste stream in sanitary landfills that has attracted the interest of a growing number of communities in Riyadh. Composting is gaining an increased interest due to the high organic matter content (OM) in MSW. Composting is a natural biological process that hastens the decomposition of organic wastes under controlled conditions. It reduces the volume of organic waste materials, creating stable and soil-enriching humus [13]. Furthermore, by transforming the municipal organic wastes into organic fertilizers, composting would complement the goal of sustainable agriculture. [14] indicated that an unclassified residual stream of MSW exists in Riyadh (organic fraction, $52.0 \%$; paper, $20.0 \%$; plastic, $18.1 \%$, textile, $2.0 \%$; wood $1.30 \%$; glass $2.83 \%$; metals, $2.80 \%$; and other, $0.97 \%$ ). The municipal organic wastes residual stream that can be composted means an average of about $52 \%$ of MSW. Serious environmental problems appear if these municipal organic wastes of MSW are not transformed into compost. Therefore, the main aim of this study was to evaluate the composting process and the characterization of its municipal organic wastes as a treatment method for the sustainable management and recycling of MSW generated in Riyadh, Saudi Arabia.

\section{Materials and Methods}

Samples of raw MSW were collected from three different districts of the city, varying in economic levels, i.e., high, middle, and low socioeconomic areas. The organic fraction of the MSW, which mainly constitutes vegetable, fruit, and kitchen wastes, was composted in a windrows composting system, in which piles are mechanically turned to obtain the compost. Three mixtures of composting piles were prepared:

- Pile 1: Mixture of one ton municipal organic wastes without any accelerator as control.

- Pile 2: One ton municipal organic wastes and a chemical accelerator composed of $50 \mathrm{~kg}\left(\mathrm{NH}_{4}\right)_{2} \mathrm{SO}_{4}$ $+6 \mathrm{~kg} \mathrm{Ca}\left(\mathrm{H}_{2} \mathrm{PO}_{4}\right)_{2}+2.25 \mathrm{~kg} \mathrm{~K}_{2} \mathrm{SO}_{4}+40 \mathrm{~kg} \mathrm{CaCO}_{3}$.

- Pile 3: One ton municipal organic wastes and organic accelerator composed of $300 \mathrm{~kg}$ sewage sludge.

The trapezoidal piles are laid down in dimensions of $2.5 \mathrm{~m} \times 3.5 \mathrm{~m} \times 1.5 \mathrm{~m}$. The piles were moistened with water to about $55 \%$ moisture content. The excess water that leached from the piles was collected and re-added to the respective piles. The surface of the piles was covered with a thin layer of clay for 90 days. During this period, the piles were turned over three times at intervals of 15,30 , and 60 days from the start of the experiment. Moisture content was checked during the composting intervals using a Hydrosense moisture meter (Campbell Scientific, Inc., USA). The initial C/N ratios in piles 1,2 , and 3 were: 20.1, 18.4, and 16.8, respectively. The temperature of the piles was measured by inserting a thermometer into the center of the piles, which were left for 12 weeks to mature. The composting process was considered complete when the temperatures of the piles were stable and close to that of the ambient temperature.

\section{Compost Samples and Analysis}

Representative compost samples with three replicates were taken from the piles at different composting time intervals (initial, 4,8 , and 12 weeks). Changes in temperature, $\mathrm{pH}$, electrical conductivity (EC), total $\mathrm{N}$, total $\mathrm{C}, \mathrm{C} / \mathrm{N}$ ratio, total $\mathrm{P}$, total $\mathrm{K}$, DTPA-extractable contents of micronutrient $(\mathrm{Zn}, \mathrm{Fe}, \mathrm{Mn}$, and $\mathrm{Cu}$ ), and heavy metals $(\mathrm{Cr}, \mathrm{Pb}$, and $\mathrm{Cd})$ were also measured. Total $\mathrm{N}$ and $\mathrm{C}$ contents were measured using a Perkin-Elmer CHNS/O Analyzer (Model 2400, Waltham, MA, USA). Organic matter (OM) was analyzed by determining the loss-on ignition at $430^{\circ} \mathrm{C}$ for $24 \mathrm{~h}$. The $\mathrm{pH}$ and EC values were measured in the 1:5 (w/v) suspension using a $\mathrm{pH}$ and EC meters, respectively. Compost samples were digested with concentrated $\mathrm{HNO}_{3}-\mathrm{HClO}_{4}$ acids at a $3: 2(\mathrm{v} / \mathrm{v})$ ratio and analyzed for total $\mathrm{Zn}, \mathrm{Fe}, \mathrm{Mn}$, $\mathrm{Cu}, \mathrm{Cr}, \mathrm{Pb}$, and $\mathrm{Cd}$ contents using an induction-coupled plasma-mass spectrometer (ICP-MS, Perkin-Elmer, USA). In the acid extract of the $\mathrm{HNO}_{3}-\mathrm{HClO}_{4}$ digestion, $\mathrm{P}$ was assessed colorimetrically by the molybdovanadate 
method, while K was determined by flame photometry (Jenway PFP7 Flame Photometer, Jenway Ltd., Felsted, Dunmow, Essex, UK). The germination index (GI) was determined using seeds of Raphanus sativus L., according to the method described by Bustaman et al., 2008 [15].

\section{Statistical Analysis}

Data collected for all studied parameters were analyzed for comparison of treatments means using

a)

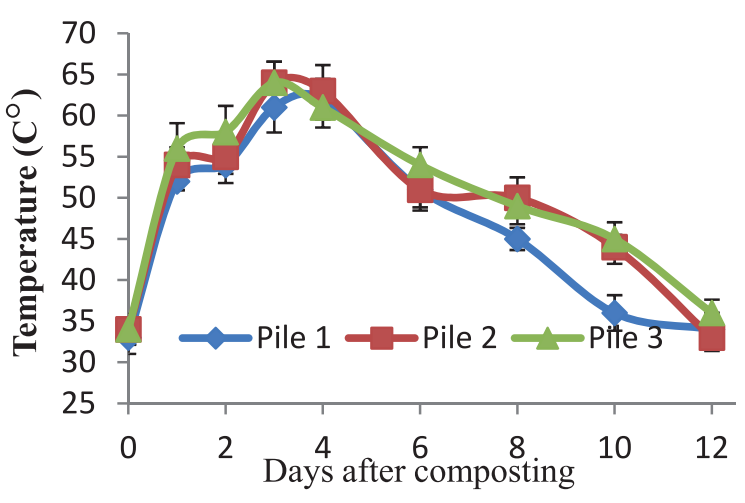

c)

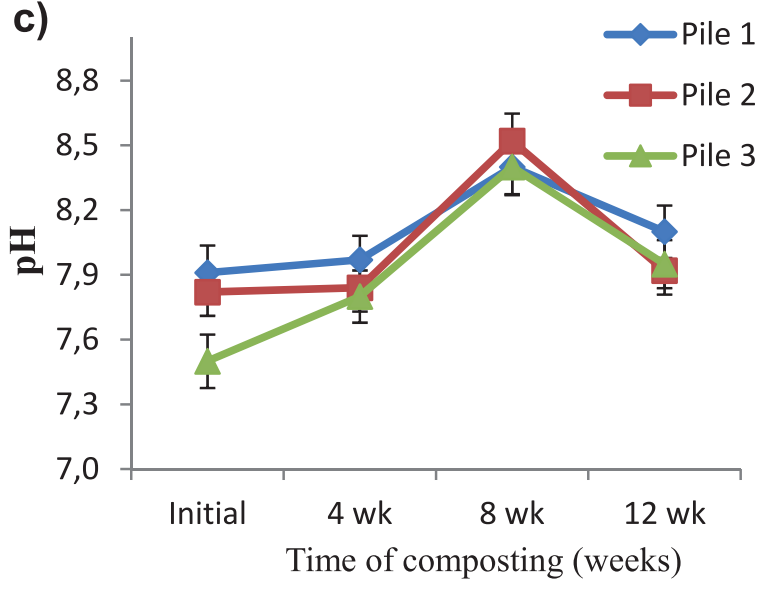

e)

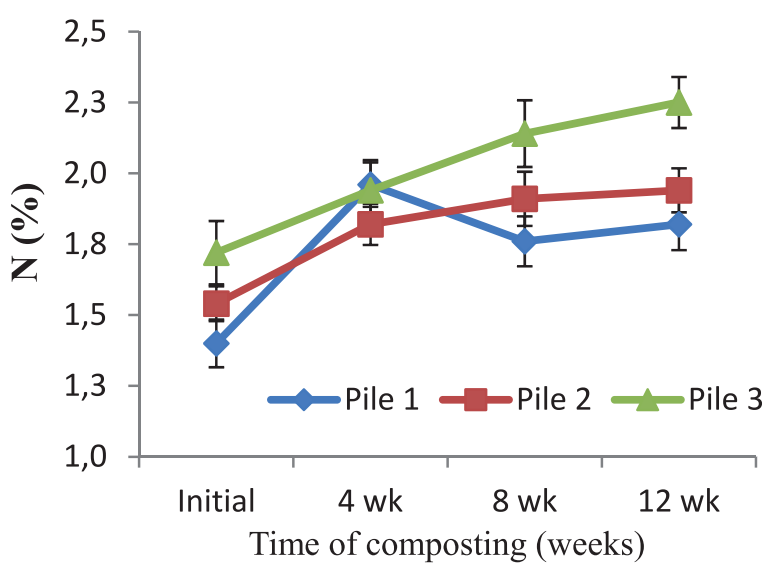

Statistics 8.0 and were compared by contrast analysis at $5 \%$ probability level.

\section{Results and Discussion}

Temperature Evolution of the Composting Piles

Temperature changes were found to be higher during the first 3-4 weeks of composting and reaching a peak between $61^{\circ} \mathrm{C}$ and $64^{\circ} \mathrm{C}$ (Fig. 1a).
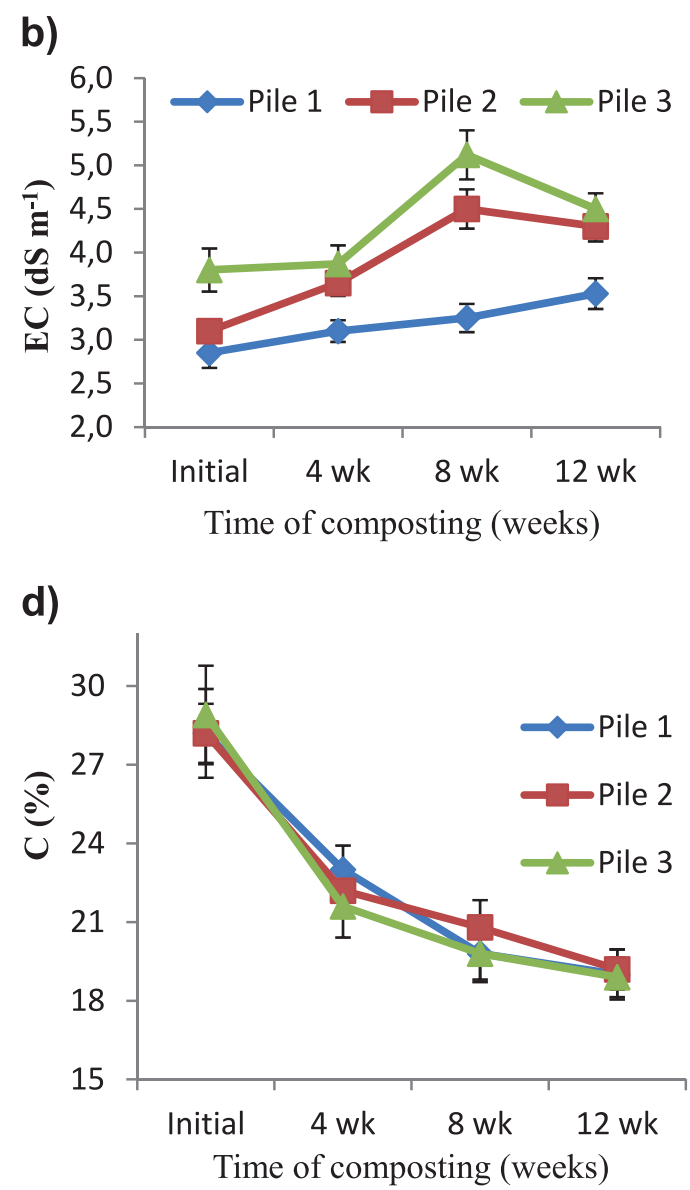

f)

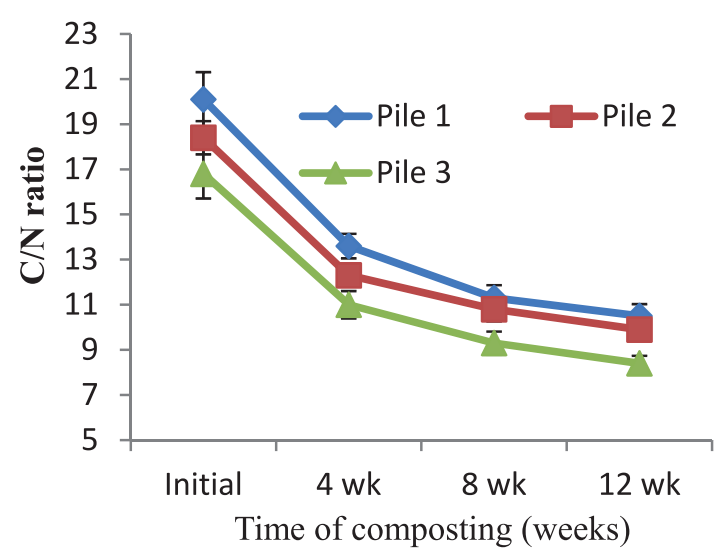

Fig. 1. Changes of: a) temperature, b) $\mathrm{EC}, \mathrm{c}) \mathrm{pH}, \mathrm{d}$ ) carbon, e) nitrogen, and $\mathrm{f}$ ) $\mathrm{C} / \mathrm{N}$ ratio during the composting process; error bar represents \pm standard error (SE, $n=4)$. 
After 6 weeks of composting, temperature decreased in the different piles until the end of the experiment and varied from $35^{\circ} \mathrm{C}$ to $50^{\circ} \mathrm{C}$. The results indicated that the temperature increased due to the oxidation of $\mathrm{C}$ to $\mathrm{CO}_{2}$ and subsequent generation of heat. After the reduction in volatile solids, the temperature decreased. Similar results were reported by Mitelut and Popa, 2011; Wongwilawalin et al., $2011[16,17]$.

\section{Changes in $\mathrm{EC}$ and $\mathrm{pH}$}

Fig. 1b shows that the EC $\left(\mathrm{dS} \mathrm{m}^{-1}\right)$ trend increased in composting piles with increased composting times. The highest EC values were recorded in pile 3, possibly due to the loss of weight and release of salts, such as $\mathrm{NH}_{4}^{+}$and phosphate ions during the organic substances decomposition $[18,19]$.

The $\mathrm{pH}$ changes are shown in (Fig. 1c) describing that $\mathrm{pH}$ values consistently increased as the composting process progressed up to 8 weeks of composting, and then decreased toward the end of the experiment. The $\mathrm{pH}$ value increased in piles 2 and 3 , and ranged from 8.40 to 8.50 at 8 weeks after composting. This increase in $\mathrm{pH}$ values during composting may be attributed to the consumption of organic acids and the release of $\mathrm{NH}_{4}^{+}$ions $[20,21]$.

\section{Changes in $\mathrm{C} / \mathrm{N}$ Ratio}

Fig. 1d shows a faster rate of $\mathrm{C}$ decomposition in piles up to 12 weeks from composting. These results are supported by the findings of Mohmoud and Ghoneim, 2016 [22]. The reduction of total $\mathrm{C}$ was greater as compared to total $\mathrm{N}$ in all types of composting processes because microorganisms used $\mathrm{C}$ as a source of energy and $\mathrm{N}$ for building cell structure in decomposition processes. Total $\mathrm{N}$ content (Fig. 1e) increased up to week 8 in all different piles and after that it remained stable up to week 12 . The increases in $\mathrm{N}$ content could be attributed to $\mathrm{N}$ losses in the form of $\mathrm{NH}_{3}$ gas $[23,24]$. The $\mathrm{C} / \mathrm{N}$ ratio (Fig. 1f) decreased rapidly from an initial value ranged from 16.8-20.1 to 9.30-11.3 after 8 weeks of composting time, and after that it continued to decrease to a final $\mathrm{C} / \mathrm{N}$ value of $8.32-10.5$. The decrease in the $\mathrm{C} / \mathrm{N}$ ratio may be attributed to the transformation of organic $\mathrm{C}$ to $\mathrm{CO}_{2}$ followed by a decrease in organic acid content $[25$, 26].

\section{Total Micronutrient Analysis}

Total and DTPA-extractable micronutrient contents measured in the study are presented in (Tables 1 and 2). A similar increase in total micronutrient contents was observed in all of the piles during the composting experience. The increases in total $\mathrm{Zn}, \mathrm{Fe}$, $\mathrm{Mn}, \mathrm{Cu}, \mathrm{Cr}, \mathrm{Cd}$, and $\mathrm{Pb}$ contents could be attributed to decreases in piles mass due to organic matter decomposition [27-29].

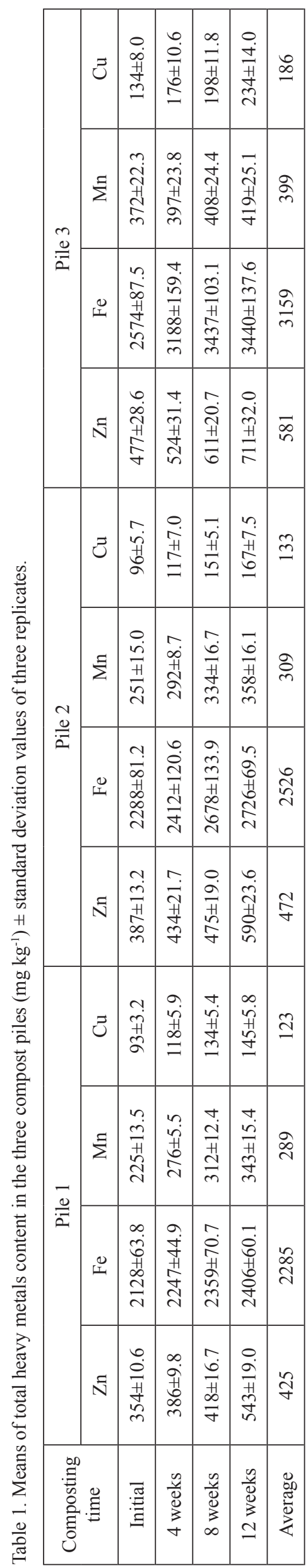


Table 2. Total DTPA-extractable heavy metal contents in the three compost piles $\left(\mathrm{mg} \mathrm{kg}^{-1}\right)$ at different composting times.

\begin{tabular}{|c|c|c|c|c|c|c|c|c|c|}
\hline \multirow{2}{*}{$\begin{array}{c}\text { Composting } \\
\text { time }\end{array}$} & \multicolumn{4}{|c|}{ Pile 1 } & \multicolumn{3}{|c|}{ Pile 2 } & \multicolumn{3}{c|}{ Pile 3} \\
\cline { 2 - 11 } & $\mathrm{Cr}$ & $\mathrm{Pb}$ & $\mathrm{Cd}$ & $\mathrm{Cr}$ & $\mathrm{Pb}$ & $\mathrm{Cd}$ & $\mathrm{Cr}$ & $\mathrm{Pb}$ & $\mathrm{Cd}$ \\
\hline Initial & $5.35 \pm 0.32$ & $32 \pm 0.96$ & 0.00 & $4.92 \pm 0.30$ & $32 \pm 1.92$ & 0.00 & $31.8 \pm 1.91$ & $86.0 \pm 5.16$ & $2 \pm 0.12$ \\
\hline 4 weeks & $6.90 \pm 0.41$ & $48 \pm 0.87$ & 0.00 & $7.20 \pm 0.36$ & $44 \pm 1.76$ & 0.00 & $35.9 \pm 1.08$ & $89.0 \pm 5.34$ & $2 \pm 0.12$ \\
\hline 8 weeks & $7.70 \pm 0.31$ & $51 \pm 2.04$ & 0.00 & $8.50 \pm 0.34$ & $55 \pm 2.75$ & 0.00 & $43.8 \pm 2.19$ & $96.0 \pm 3.26$ & $2 \pm 0.07$ \\
\hline 12 weeks & $6.96 \pm 0.38$ & $67 \pm 1.68$ & 0.00 & $7.13 \pm 0.29$ & $74 \pm 2.96$ & 0.00 & $48.5 \pm 2.18$ & $107 \pm 4.82$ & $2 \pm 0.09$ \\
\hline Average & 6.73 & 49.5 & 0.00 & 6.94 & 51.3 & 0.00 & 40.0 & 94.5 & 2.00 \\
\hline
\end{tabular}

Results are expressed as mean \pm standard deviation of three replicates.

\section{Quality of the Matured Compost}

Table 3 presents the main properties of the final composts. After the curing process, the compost was dark brown in colour and had an earthy smell. The $\mathrm{C} / \mathrm{N}$ ratio, which indicates the maturity of composts, always varied between 8.40 to 10.4 , being less than 15 and 20 , the threshold set by $[30,31]$. $\mathrm{pH}$ values averaged $7.90,7.92$, and 7.89 in piles 1,2 , and 3, respectively. According to [32], the typical $\mathrm{pH}$ range of the produced compost fell within the range. The final $\mathrm{pH}$ range of matured compost is adequate for most of the crops.

The EC of the current study ranged between 3.53 to $4.50 \mathrm{dS} \mathrm{m}^{-1}$ - more or less similar to standard values $[33,34]$. The EC values were medium as compared with the values observed in compost obtained from MSW in previous works [35] and with compost from agricultural by-products [36]. All the compost piles showed notable contents of organic matter percentage (OM percentage

Table 3. Means of elemental analysis of mature compost piles compared to standard values

\begin{tabular}{|c|c|c|c|c|}
\hline \multirow{2}{*}{ Parameters } & \multicolumn{3}{|c|}{ Matured compost } & \multirow{2}{*}{$\begin{array}{c}\text { Standard } \\
\text { values }\end{array}$} \\
\cline { 2 - 4 } & Pile 1 & Pile 2 & Pile 3 & 4.50 \\
\hline EC $\left(1: 5 \mathrm{dS} \mathrm{m}^{-1}\right)$ & 3.53 & 4.30 & 4.50 & 7.40 \\
\hline $\mathrm{pH}(1: 5)$ & 7.90 & 7.92 & 7.84 & 35.0 \\
\hline OM (\%) & 32.9 & 33.1 & 32.2 & $3.0-15$ \\
\hline $\mathrm{C} / \mathrm{N} \mathrm{ratio}$ & 10.4 & 9.90 & 8.40 & 1.80 \\
\hline Total N (\%) & 1.82 & 1.94 & 2.25 & 0.50 \\
\hline Total P $(\%)$ & 0.46 & 0.48 & 0.50 & 0.25 \\
\hline Total K (\%) & 0.21 & 0.23 & 0.26 & 550 \\
\hline Total Zn $\left(\mathrm{mg} \mathrm{kg}^{-1}\right)$ & 425 & 472 & 581 & 5200 \\
\hline Total Fe $\left(\mathrm{mg} \mathrm{kg}^{-1}\right)$ & 2285 & 2526 & 3159 & 510 \\
\hline Total Cu $\left(\mathrm{mg} \mathrm{kg}^{-1}\right)$ & 123 & 133 & 186 & 310 \\
\hline $\mathrm{GI}(\%)$ & 95 & 90 & 90 & - \\
\hline
\end{tabular}

EC: Electrical conductivity, OM: Organic matter,

GI: Germination index. Results are expressed as mean of three replicates. average $32.7 \%$ ) comparable to other compost derived from MSW [37]. Increasing OM percentage in the produced compost is considered one of the positive features because a higher OM percentage enhances the physical properties of soil [38]. According to the average total $\mathrm{N}$ content $(1.80 \%)$, total $\mathrm{P}(0.50 \%)$, and total $\mathrm{K}(0.25 \%)$, the produced compost falls within the range of values found in compost produced from vegetables and manure [39]. The average of micronutrient contents $(\mathrm{Zn}, \mathrm{Fe}, \mathrm{Mn}$, and $\mathrm{Cu}$ ) was below the standard values suitable for compositing. The levels of heavy metal contents were: $\mathrm{Cr}$ (6.73-18.0 mg kg-1), Pb (49.0-65.1 $\left.\mathrm{mg} \mathrm{kg}^{-1}\right)$, and Cd $\left(0.66 \mathrm{mg} \mathrm{kg}^{-1}\right)$ within the acceptable limits for composting [40]. Regarding the maturity parameters, almost all the types of studied composts satisfied the criterion that indicates the disappearance of phytotoxicity in compost [41] as shown by GI values obtained, compared to a control with distilled water.

\section{Conclusions}

Riyadh in the Kingdom of Saudi Arabia faces major environmental challenges associated with municipal waste generation and inadequate waste collection, transport, treatment, and disposal. The MSW stream in Riyadh is diverse and contains a variety of organic and inorganic materials. Composting is the most appropriate economical solution to overcome the problem due to MSW. The results indicated that municipal organic fraction collected can be properly composted due to its high content of organic matter and lack of microbial decomposition suppressants. Overall, the resulting composts here showed good quality parameters that are in line with other high-standard marketed composts. Based on the results of this study, it can be conclude that composting is the best way to reduced or recycle the MSW and it causes less pollution and more benefit to the environment as well as to the economy when compared to current methods of MSW disposal into open dumps. Further studies are required to determine nutrient release and decomposition rates from this compost when applied under arid soil conditions. 


\section{Acknowledgements}

The authors appreciate and thank the College of Food and Agricultural Sciences, Research Center and Deanship of Scientific Research, King Saud University, Saudi Arabia, for financial support of this research.

\section{Conflict of Interest}

The authors declare no conflict of interest

\section{References}

1. TROSCHINETZ M., MILHECIC. J.R. Sustainable recycling of municipal solid waste in Developing Countries. Waste Management, 29, 915, 2009.

2. SUPREME COMMISSION FOR THE DEVELOPMENT OF RIYADH CITY. Archived from the original on April, 2017.

3. AL-MUTAIRI S.O., GHONEIM A.M., AL-MODAIHSH A.S., MAHJOUB M.S., REDA Y.A. Characterization and composting of municipal solid waste of Riyadh City, Saudi Arabia. In: C.A. Brebbia; G.Passerni; H.Itoh (Eds.), Waste Management and Environment VII. WIT Transactions on Ecology and the Environment (pp. 283-292). Wessex Institute of Technology, UK: WIT Press, . 2014.

4. MODAIHSH A.S., GHONEIM A.M., MAHJOUB M.O., NADEEM M.E., AL-BARAKAH,F.N. Characterizations of deposited dust fallout in Riyadh city, Saudi Arabia. Polish J. of Environmental Studies, 26 (4), 1599, 2017.

5. ASFARI A.F. Municipal solid waste management in the Arab world with particular reference to GCC Courtiers. Proc. of Oman International Conference on Waste Management, 2008.

6. ADEWALE M.T. Composting as a sustainable waste management technique in developing countries. J. Environ. Sci. and Technology, 4, 93, 2011.

7. SHARMA A., SHARMA R., ARORA A., SHAH R., SINGH A., PRANAW K., NAIN L. Insights into rapid composting of paddy straw augmented with efficient microorganism consortium. Int. J. Recycl. Org. Waste Agriculture, 3, 1, 2014.

8. ALZAYDI A.A., ALSOLAIMANI S. Utilization of organic MSW to produce various types of compost in the western region, Kingdom of Saudi Arabia. Final Report, contract No. 1/S/1, Center of Excellence in Environmental Studies, King Abdul Aziz University, Jeddah, Saudi Arabia, 2012.

9. KHARRAZI S.M., YOUNESI H., ABEDINITORGHABEH J. Microbial biodegradation of waste materials for nutrients enrichment and heavy metals removal: an integrated composting vermicomposting process. International Biodeterioration \& Biodegradation, 92, 41, 2014.

10. DAUR I. Study of commercial effective microorganism on composting and dynamics of plant essential metal micronutrients. J. of Environ. Biology, 37, 937, 2016.

11. FAUCETTE, B. Evaluation of environmental benefits and impacts of compost and industry standard erosion and sediment control measures used in construction activities." Ph.D. Dissertation, university of Georgia, Atlanta, USA, 2004.
12. BASTIDA F., MORENO J., HERNANDEZ T., GARCIA C. The long-term effects of the management of a forest soil on its carbon content, microbial biomass and activity under a semi-arid climate. Applied Soil Ecology, 37, 53, 2007.

13. GAUTAM S.P., BUNDELA P., PANDEY A., AWASTHI M., SARSAIYA S. Composting of municipal solid waste of Jabalpur city. Global J. Environ Research, 4, 43, 2010.

14. GHONEIM A.M., ELBASSIR O.I., MODAHISH A.S., MAHJOUB M.O. Compost production from olive tree pruning wastes enriched with phosphate rock. Compost Science \& Utilization, 25, 13, 2017.

15. BUSTAMANTE M, A, PAREDES C., MARHUENDAEGEA F.C., PEREZ-ESPINOSA A., BERNAL M.P., MORAL R. Co-composting distillery wastes with animal manure: carbon and nitrogen transformations and evaluation of compost stability. Chemosphere, 72, 51, 2008.

16. MITELUT A.C., POPA M.E. Seed germination bioassay for toxicity evaluation of different composting biodegradable materials. Romanian Biotechnological Letters, 16, 21, 2011.

17. WONGWILAIWALIN S., RATTANCHOMSRI U., LAOTHANACHAREON L., EURWILAIAICHILT Y., IGARASHI V., CHAMPREDA V. Analysis of a thermophilic lignocellulose degrading microbial consortium and multi-species lignocelluloytic enzyme system. Enzyme and Microbial Technology, 47, 283, 2010.

18. GONDEK K., KOPEC K., MIERZWA M., TABAK M., CHMIE M. Chemical and biological properties of composts produced from organic waste. Journal of Elementology, 19, 377, 2014.

19. GIGLIOTTI G., PROIETTI P., SAID-PULLICINO D., NASINI D., PEZZOLLA L., ROSATI L., Porceddu, P.R. Co-composting of olive husks with high moisture contents: organic matter dynamics and compost quality. International Biodeterioration and Biodegradation, 67, 8, 2012.

20. GIANNAKIS G.V., KOURGIALAS N.N., PARANYCHIANAKIS N.V., NIKOLAIDIS N.P., KALOGERAKIS, N. Effects of municipal solid waste compost on soil properties and vegetables growth. Compost Science and Utilization, 22, 116, 2014.

21. NAKASAKI K., ARAYA A., MIMOTO H. Inoculation of pichia kudriavzevii RB1 degrades the organic acids present in raw compost material and accelerates composting. Bioresource Technology, 144, 521, 2013.

22. MAHMOUD E.K., GHONEIM A.M. Effect of polluted water on soil and plant contamination by heavy metals in El-Mahla El-Kobra, Egypt. Solid Earth, 7, 703, 2016.

23. ZHOU C., LIU Z., HUANG Z.L., DONG M., YU X.L., NING P. A new strategy for co-composting dairy manure with rice straw: Addition of different inocula at three stages of composting. Waste management, 40, 38, 2015.

24. DE GUARDIA A., MALLARD A., TEGLIA C., MARIN A., LE PAPE C., LAUNAY M., BENOIST J.C., PETIOT C. Comparison of five organic wastes regarding their behavior during composting: Part 1,biodegradability, stabilization kinetics and temperature rise. Waste Management, 30, 402, 2010.

25. SANMANEE N., PANISHKAN K., OBSUWAN K., DHARMVANIJ S. Study of compost maturity during humification process using UV Spectroscopy. World Acad Sci Eng Technology, 80,403, 2011. 
26. MAKNI H., AYED L., BEN KHEDHER B., BAKHROUF, A. Evaluation of the maturity of organic waste composts. Waste Management \& Research, 28, 489, 2010.

27. ZHANG M., HEANEY D., HENRIQUEZ B., SOLBERG E., BITTNER E. A four-year study on influence of biosolids/MSW compost application in less productive soils in Alberta: nutrient dynamics. Compost Science \& Utilization, 14, 68, 2006.

28. ZHANG Y.G., ZHANG Y.Y., CAI J.P., ZHU P., GAO H.J., JIANG, Y. Variation in available micronutrients in black soil after 30 -year fertilization treatment. Plant Soil Environment, 60, 387, 2014.

29. COLON J., MARTINEZ-BLANCO J., GABARELL X., ARTOLA A., SANCHEZ A., RIERDEVALL A. Environmental assessment of home composting. Resources, Conservation and Recycling, 54, 893, 2010.

30. MOLDES A., CENDON Y., BARRAL M.T. Evaluation of municipal solid waste compost as a plant growing media component by applying mixture design. Bioresource Technology, 98, 3069, 2007.

31. BARBERA A., MAUCIERI C., CAVALLARO V., IOPPOLO A., SPAGNA G. Effects of spreading olive mill wastewater on soil properties and crops. A Review Agricultural Water Management, 119, 43, 2013.

32. BUSTAMANTE M.A., ALBURQUERQUE J.A., RESTREPO A.P, DE LA FUENTE C., PAREDES C., MORAL R., BERNAL M.P. Co-composting of the solid fraction of anaerobic digestates, to obtain added-value materials for use in agriculture. Biomass Bioenergy, 43, 26, 2012.

33. TOGNETTI C., MAZZARINO M.J., LAOS F. Improving the quality of municipal organic waste compost. Bioresource Technology, 98, 1067, 2007.
34. TOGNETTI C., MAZZARINO M.J., LAOS F. Composting biosolids and municipal organic waste: effects of process management on stabilization and quality. Biol. Fertil. Soils, 43, 387, 2007b.

35. WALTER I., MARTÍNEZ N., CUEVAS G. Plant and soil responses to the application of composted MSW in a degraded, semiarid Shrubland in Central Spain. Compost Science \& Utilization, 14,147, 2006.

36. ABAD M.P. Noguera and S. Burés: National inventory of organic wastes for use as growing media for ornamental potted plant production: case study in Spain. Bioresour Technolgy, 77, 197, 2001.

37. AVIANI I., LAOR Y., MEDINA S., KRASSNOVSKY A., RAVIV M. Co-composting of solid and liquid olive mill wastes: management aspects and the horticultural value of the resulting composts. Bioresource Technology, 101, 6699, 2010

38. HARGREAVES J.C, ADL M.S., WARMAN P.R. A review of the use of composted municipal solid waste in agriculture. Agric. Ecosystem Environment, 123, 1, 2008.

39. HERRERA F., CASTILlO J.E, CHICA A.F., LOPEZ BELLIDO L. Use of municipal solid waste as a growing medium in the nursery production of tomato shoots. Bioresource Technology, 99, 287, 2008.

40. APARNA C., SARITHA P., HIMABINDU V., ANJANEYULU Y. Techniques for the evaluation of maturity for composts. Waste Management, 28, 1773, 2008.

41. BOE. REAL Decereto506/2013, de 28 De Junio, sobre productors fertiliantes. BOE, 164, 51119, 2013. 